\title{
Non-programmed transcriptional frameshifting is common and highly RNA polymerase type-dependent
}

\author{
Dawid Koscielniak, Ewa Wons, Karolina Wilkowska and Marian Sektas *i)
}

\begin{abstract}
Background: The viral or host systems for a gene expression assume repeatability of the process and high quality of the protein product. Since level and fidelity of transcription primarily determines the overall efficiency, all factors contributing to their decrease should be identified and optimized. Among many observed processes, non-programmed insertion/deletion (indel) of nucleotide during transcription (slippage) occurring at homopolymeric $A / T$ sequences within a gene can considerably impact its expression. To date, no comparative study of the most utilized Escherichia coli and T7 bacteriophage RNA polymerases (RNAP) propensity for this type of erroneous mRNA synthesis has been reported. To address this issue we evaluated the influence of shift-prone $A / T$ sequences by assessing indel-dependent phenotypic changes. RNAP-specific expression profile was examined using two of the most potent promoters, $P_{\text {araBAD }}$ of E. coli and $\varphi 10$ of phage T7.
\end{abstract}

Results: Here we report on the first systematic study on requirements for efficient transcriptional slippage by T7 phage and cellular RNAPs considering three parameters: homopolymer length, template type, and frameshift directionality preferences. Using a series of out-of-frame gfp reporter genes fused to a variety of A/T homopolymeric sequences we show that T7 RNAP has an exceptional potential for generating frameshifts and is capable of slipping on as few as three adenine or four thymidine residues in a row, in a flanking sequence-dependent manner. In contrast, bacterial RNAP exhibits a relatively low ability to baypass indel mutations and requires a run of at least 7 tymidine and even more adenine residues. This difference comes from involvement of various intrinsic proofreading properties. Our studies demonstrate distinct preference towards a specific homopolymer in slippage induction. Whereas insertion slippage performed by T7 RNAP (but not deletion) occurs tendentiously on poly $(A)$ rather than on poly $(T)$ runs, strong bias towards poly $(\mathrm{T})$ for the host RNAP is observed.

Conclusions: Intrinsic RNAP slippage properties involve trade-offs between accuracy, speed and processivity of transcription. Viral T7 RNAP manifests far greater inclinations to the transcriptional slippage than E. coli RNAP. This possibly plays an important role in driving bacteriophage adaptation and therefore could be considered as beneficial. However, from biotechnological and experimental viewpoint, this might create some problems, and strongly argues for employing bacterial expression systems, stocked with proofreading mechanisms.

Keywords: Recombinant proteins, E. coli RNAP, T7 bacteriophage RNAP, Expression system, GFP reporter, Transcriptional slippage, Indel errors

*Correspondence: marian.sektas@biol.ug.edu.pl

Department of Microbiology, Faculty of Biology, University of Gdansk,

Wita Stwosza 59, 80-308 Gdansk, Poland 


\section{Background}

Random fluctuation in promoter activity influenced by intrinsic and extrinsic factors causing cell-to-cell variability in the mRNA level during expression of an individual gene is referred to as genetic noise [1-4]. It creates a selective advantage for competing strains by allowing response to changes in the environment. More specifically, phenotypic variability in clonal populations of microbial cells can be generated by various epigenetic events [5-8]. Changes in the gene expression pattern are triggered by factors which alter the genetic record without affecting the primary DNA sequence [9-12]. Among them, the programmed transcriptional realignment contributing to the site specific RNA editing appears to have the most influential impact on gene expression and regulation [11, 13-15]. However, our knowledge on nonprogrammed, "accidental" nucleotide indel errors in slippage-prone $\mathrm{A} / \mathrm{T}$ tracts, remains incomplete, and thus its real impact on gene expression profile may be underestimated. Recently, an incredible propensity for slippage on many homopolymeric regions within a given gene found for T7 and E. coli RNAPs resulted in a production of a broad spectrum of protein variants with some aminoacid alterations [16]. Productive transcriptional slippage at such sites involves unwinding-rewinding of the RNA:DNA hybrid which is not sensed by RNAP active site and thereby does not lead to the enzyme's backtracking and mRNA correction. Dissociation of 8-9 nucleotide duplex and re-pairing is much more plausible within a series of identical nucleotides than a random mixed sequence. According to the thermodynamic model many microscopic base slippage events can lead to local RNA displacements $[17,18]$. Decrease in fidelity may result from poor stability of the 3 -proximal part of the hybrid which occurs at A-U rich tracts. Long mononucleotide A/T stretches destabilize and realign RNA:DNA hybrid, contributing to a slip of RNAP on the DNA template. Studies focused on influence of the A/T homopolymeric regions on helix structures revealed their unusual properties, modifying the normal conformation of B-DNA model [19-23]. In this light the poly $(\mathrm{A} / \mathrm{T})$ tracts are considered as structures potentially promoting a less accurate transmission of genetic information. Accordingly, the poly(A) homopolymer regions are more tightly wound ( $10.1 \pm 0.1$ base pairs per turn). The adenine N-6 amines of the one strand and thymine O-4 of the subsequent base pair of the opposite strand can form crosschain hydrogen bonds which stabilize a large propeller twist in the A-T base pairs. As was demonstrated, rA:dT polypurine hybrids have a severely distorted structure, encompassing altered base pairing (weakened pairing, mispairing and unpairing) which leads to an unzipped structure, found in free RNA:DNA hybrids as well as in a complex with HIV reverse transcriptase [24, 25]. Molodtsov et al. [26] regarded poly(U/A) structural abnormalities as the prerequisite for the transcription termination by T7 and SP6 RNAPs. A plausible model of the nucleotide misincorporation during T7 phage, yeast, Thermus thermophilus and E. coli RNAP transcription is the template strand misalignment by temporary flipping-out of a base [17, 27-29].

Indel type of transcriptional errors may be considered as ambiguous. One on hand, they are detrimental to efficiency of gene expression, but on the other hand under certain conditions they can also be beneficial for cell physiology. The level of expression and multispecificity of numerous genes (phenotypic variation) may be regulated in this way $[6,30,31]$. Moreover, transcriptional slippage has significant potential to restore the wild-type phenotype of indel mutant genes [10, 16, 32-36]. In fact, epigenetic effects caused by transcriptional slippage have been found during all steps of the transcription process in E. coli, particularly at homopolymeric stretches of $\mathrm{A} / \mathrm{T}$, which appear to be hot-spots for subsequent phenotypic changes [16, 34, 37-40].

In this work, we are presenting comparative analysis of the transcriptional slippage propensity of the two most used RNA polymerases: E. coli and T7 bacteriophage, representing two different enzyme families [41]. In our study, we used a set of poly(A/T) sequence variants translationally fused to downstream located out-of-frame green fluorescent protein gene $(g f p)$ of Aequorea victoria, which allowed to monitor the most frequent, single nucleotide insertion and deletion in mRNA. Depending on the specific sequence context we noticed up to several fold greater slippage ability of T7 RNAP than the host polymerase. These enzymes also differ in their preference towards homopolymeric tracts. T7 RNAP is similarly error prone on both poly $(\mathrm{A} / \mathrm{T}) \mathrm{s}$, while the host polymerase is conspicuously more liable to slippage on poly $(\mathrm{T})$ s. Obtained results, despite addressing only one aspect of mRNA synthesis fidelity, reflect two interesting and important distinct survival strategies. In case of highly organized bacterial cells the aim is to avoid any unfavorable mutations, while for bacteriophage the changes may turn out to bear an adaptive advantage.

\section{Materials and methods}

\section{Bacterial strains and plasmids}

Escherichia coli (E. coli) DH10B $\left(\mathrm{F}^{-} \lambda^{-}\right.$mcrA $\Delta(m r r-$ hsdRMS-mcrBC) $\Phi 80 l a c Z \Delta \mathrm{M} 15 \Delta l a c \mathrm{X} 74$ recA1 endA1 araD139 $\Delta$ (ara leu) 7697 gal $\mathrm{U}$ gal $\mathrm{K}$ rpsL nup $\mathrm{G})$ and ER2566 ( $\mathrm{F}^{-} \lambda^{-}$fhuA2 [lon] omp T lacZ::T7 gene 1 gal sulA11 $\Delta$ (mcrC-mrr)114::IS10 R(mcr-73::miniTn10$\left.\mathrm{Tet}^{\mathrm{S}}\right) 2 \mathrm{R}\left(z g b-210:: \operatorname{Tn} 10-\mathrm{Tet}^{\mathrm{S}}\right)$ endA1 [dcm]) both from New England Biolabs were used as a cloning and/or 
expressing host. Plasmid pGreenTIR was a source of enhanced fluorescence eGFP variant (F64L/S65T) [42]. E. coli cells were grown in Luria-Bertani (LB) broth or agar [43] with antibiotics (Sigma) at the following concentrations: ampicillin (Ap), $100 \mu \mathrm{g} \mathrm{ml}^{-1}$; chloramphenicol $(\mathrm{Cm}), 25 \mu \mathrm{g} \mathrm{ml}^{-1}$; kanamycin $(\mathrm{Km}), 50 \mu \mathrm{g} \mathrm{ml}^{-1}$; and tetracycline (Tet) $15 \mu \mathrm{g} \mathrm{ml}^{-1}$, chlorotetracycline (cTc) $20 \mu \mathrm{g} \mathrm{ml}^{-1}$, bicyclomycin (BMC, Cayman Chemicals) 5 $100 \mu \mathrm{g} \mathrm{ml}^{-1}$. Plasmids used in this work (Additional file 1: Table S1) were introduced into the cells by a standard chemical transformation procedure [43]. For each experiment freshly transformed cell were used. After reaching mid-log phase, the appropriate cell culture was supplemented with L-arabinose (Sigma) or IPTG (isopropyl- $\beta$ D-1-thiogalactopyranoside, Sigma) at a concentration at $0.1 \%$ and $1 \mathrm{mM}$, respectively, and the cells were harvested after $1 \mathrm{~h}$ of additional incubation.

\section{Strain construction}

Escherichia coli MC1061DgreAgreB strain was constructed by two-step P1vir transduction [43] with the following donors: CF15971 [44] as a source of $\triangle$ greA::cat, and CF15977 as a source of $\triangle g r e B:: k a n$. Both strains were obtained from Dr. K. Potrykus.

\section{Plasmids construction}

Construction of plasmids employed combination of PCR and subcloning techniques to provide variants of the mboIIM2 gene, mboIIM2-gfp or poly(AT)-gfp as translational fusion genes inserted into pBAD24 [45] or pET24a (Novagene, USA) expression vectors, containing the $\mathrm{P}_{\text {araBAD }}$ or $\phi 10$ of T7 phage promoter, respectively. All details concerning plasmid constructs are given in Additional file 1: Table S1.

\section{Genetic techniques}

Standard protocols [43] and kits were used for purification of plasmid DNA (A\&A Biotechnology, Poland), DNA digestion with restriction endonucleases, DNA ligation with T4 DNA ligase, PCR techniques with PfuPlus DNA polymerase (all from Eurx-Gdansk, Poland), as well as for DNA sequencing of the mboIIM2 mutated derivatives (Genomed, Poland).

\section{Single and multiple site-directed mutagenesis}

Indel variants of DNA methyltransferase mboIIM2 from Moraxella bovis ATCC 10900 [46] were constructed by introducing nucleotide deletion/insertion in reverse primers. Supplementary tables include a list of plasmids with details of their construction and oligonucleotides used (Additional file 1: Tables S1 and S2, respectively). Site-specific mutagenesis using PCR was carried by high fidelity PfuPlus DNA polymerase (Eurx-Gdansk, Poland) according to the manufacturer's instructions (50 ng of plasmid template was added to a 50- $\mu$ l PCR mix). Appropriate plasmid templates were PCR-amplified and then $1 \mu \mathrm{l}(10 \mathrm{u})$ of the DpnI enzyme (Fermentas) was added directly to reactions to eliminate the parental plasmid DNA. Following a-1.5-h incubation at $37{ }^{\circ} \mathrm{C}$, the DNA products were resolved in agarose gels, appropriate bands were cut out and aliquots containing purified DNA were transformed into DH10B competent cells. All plasmid modifications were confirmed by Sanger DNA sequencing using the BigDye Terminator v3.1 (Applied Biosystems, USA) (Genomed, Poland).

\section{Segmental analysis of mbollM2 gene transcripts decay by real-time $\mathrm{qRT}$-PCR and northern blotting detection}

Cellular RNA collected for RT-qPCR and northern blot analyses was extracted using the Total RNA Mini Kit (A\&A Biotechnology Poland) according to the manufacturer's instructions. RNA from individual sample extraction ( $8 \mu \mathrm{l}$ out of $80 \mu \mathrm{l}$ total RNA) was used in each $20 \mu \mathrm{l}$ reaction for cDNA synthesis (Thermo Scietific). The specific forward and reverse primers used for testing mboIIM2 variants mRNA and internal controls are shown in Additional file 1: Table S2. Eurx Taq DNA polymerase kits (Eurx, Gdansk Poland) were used to prepare the master mix for each sample. Real-time RT-qPCR tested five regions of a transcript covering the whole gene. PCR employed the following cycling parameters: $95{ }^{\circ} \mathrm{C}$ for $2 \mathrm{~min}$, followed by 35 cycles of $94{ }^{\circ} \mathrm{C}$ for $5 \mathrm{~s}$, $59{ }^{\circ} \mathrm{C}$ for $5 \mathrm{~s}$, and $72{ }^{\circ} \mathrm{C}$ for $15 \mathrm{~s}$; the melting curve (59$94{ }^{\circ} \mathrm{C}$ ) program was used for quality control. qRT-PCR was carried out by performing three independent experiments, each in triplicate, in a Lightcycler 2.0 instrument (Roche Diagnostics, Indianapolis, IN, USA) according to the manufacturer's recommendations by using the SYBR Green real-time PCR kit (Eurx, Gdansk, Poland). In all studies the decay characteristics of the upstream and downstream mRNA segments were normalized to stable reference $c y s G$ housekeeping gene [47]. The relative foldchange in mRNA ratios were obtained by normalizing each time point data in reference to the earliest measurement [48].

The mboIIM2 gene variants' specific transcript profiles were detected by northern blotting. Equal amounts $(8 \mu \mathrm{g})$ of total RNA from different time intervals were loaded on formaldehyde $1.3 \%$ agarose denaturing gel and then transferred onto a nitrocellulose membrane (Zeta-Probe, BioRad) by capillary forces. PCR-produced dsDNA fragment of $380 \mathrm{bp}$ (primers used were Mbo2F and InterR specific to $5^{\prime}$ half of the gene sequence) (Additional file 1: Table S2) was biotin labeled (Biotin-High Prime, Roche) and used for hybridization at $42{ }^{\circ} \mathrm{C}$. Chemiluminescent detection was carried out using streptavidin-HRP Pierce 
ECL substrate (Thermo Fisher Scientific) followed by exposure on X-ray film.

\section{Assessment of mbollM2 mRNA nucleotide polymorphism by NGS approach}

Preparation of cDNA templates (pBADmboII $\triangle \mathrm{A} 356$ ) from arabinose induced cells $(0.1 \%$ for $2 \mathrm{~h})$ was performed exactly as described previously [16]. Similarly, the NGS procedure was performed by Genomed Ltd. (Warsaw, Poland).

\section{Western blotting}

ER2566 cells harboring various pET24a-mboIIM2/gfp plasmids or DH10B carrying pBAD-mbolIM2/gfp plasmids were grown in $\mathrm{LB}$ medium at $37{ }^{\circ} \mathrm{C}$ and induced with $1 \mathrm{mM}$ IPTG or $0.1 \% \mathrm{~L}$-arabinose for up to $3 \mathrm{~h}$, respectively. Protein samples $(100-200 \mu \mathrm{l}$ each) were electrophoresed on a 10-12.5\% SDS-polyacrylamide gel (PAGE) and electroblotted onto a nitrocellulose membrane (Bio-Rad) using semi-dry transfer system (Pierce G2 Fast Blotter) according to the manufacturer's instructions (Thermo Scientific). Next, the membrane was blocked for at least $1 \mathrm{~h}$ in the PBS buffer $(137 \mathrm{mM}$ $\mathrm{NaCl}, 2.7 \mathrm{mM} \mathrm{KCl}, 10 \mathrm{mM} \mathrm{Na} \mathrm{HPO}_{4}, 2 \mathrm{mM} \mathrm{KH}_{2} \mathrm{PO}_{4}$ $\mathrm{pH} 7.4$ ) with $5 \%$ skimmed milk. The membrane was then probed with rabbit polyclonal anti-M2.MboII [46, 49] or mouse monoclonal anti-GFP (B-2) antibodies (Santa Cruz Biotechnology, USA), diluted 1:2000 and 1:4000, respectively, in TBS-T buffer $(50 \mathrm{mM}$ Tris- $\mathrm{HCl}, 150 \mathrm{mM}$ $\mathrm{NaCl}, 0.05 \%$ Tween $20, \mathrm{pH} 7.6$ ) with $5 \%$ skimmed milk, for $1.5 \mathrm{~h}$ at room temperature. After three washes with TBS-T, the membrane was incubated for $1 \mathrm{~h}$ with goat anti-rabbit secondary antibody conjugated with alkaline phosphatase (AP, 1:30,000, Sigma), for $1 \mathrm{~h}$ at room temperature, or with a chicken anti-mouse IgG-HRP (horseradish peroxidase, 1:5000, Santa Cruz Biotechnology). The membrane was washed three times and a specific protein was visualized by adding BCIP/NBT solution (Fermentas) or by adding a chemiluminescent substrate solution (Pierce ECL Plus Western Blotting Substrate, Thermo Scientific) and exposed to X-ray film.

\section{Analysis of the $\mathrm{N}$-terminal amino acid sequence of truncated variants of $\mathrm{M} 2$.Mboll}

$\mathrm{N}$-terminal GFP protein sequence analysis was performed at BioCentrum Ltd. (Krakow, Poland). Sequentially detached phenylthiohydantoin derivatives of amino acids were identified using the Procise 491 (Applied Biosystems, Foster City, USA) automatic sequence analysis system, according to the standard protocol of the manufacturer.

\section{Quantification of GFP fluorescence}

For fluorescence measurements of GFP hybrid proteins, freshly transformed cells were used. Several colonies of each were transferred into $5 \mathrm{ml} \mathrm{LB}$ medium and grown until mid-log phase. To induce expression of studied genes IPTG (to $1 \mathrm{mM}$ ) or arabinose (to $0.1 \%$ ) were added, and cells were grown for an additional hour. A total of $400 \mu \mathrm{l}$ of each cell culture were centrifuged at $3500 \mathrm{rpm}$ for $6 \mathrm{~min}$, supernatant was discarded and the pellet was resuspended in $200 \mu \mathrm{l}$ of the F buffer (M9 salts; $0.1 \mathrm{mM}$ $\left.\left.\mathrm{CaCl}_{2} ; 1 \mathrm{mM} \mathrm{MgSO}\right)_{4}\right)$. Fluorescence intensity of the set of poly(A/T)-gfp fusions (i.e. eGFP $[50,51]$ ) was quantified using a Varioskan ${ }^{\circledR}$ Flash Spectral Scanning Multimode Reader spectrophotometer (Thermo Scientific) at excitation and emission wavelengths of 485 and $510 \mathrm{~nm}$, respectively, using 96-well black plates (400 $\mu \mathrm{l}$ sample). Samples were assayed in at least three triplicate repetitions. Fluorescence from $g f p$-less cells was taken as background and subtracted from all values. Strains containing in-frame $g f p A_{6} O$ and $g f p T_{6} O$ fusions were used as positive controls and were taken as 100\% [52].

\section{Fluorescence microscopy}

Samples of ER2566 bacterial cultures $(0.1 \mathrm{ml})$ bearing a $g f p$-tagged reporter were studied with fluorescence microscopy. Cell membranes were stained with SynaptoRed C2 (FM4-64) fluorescent dye (Sigma) at a final concentration of $5 \mu \mathrm{g} \mathrm{ml}^{-1}$ for $10 \mathrm{~min}$. The DNA was visualized by staining with DAPI (4,6-diamidino-2-phenylindole) at $1 \mu \mathrm{g} \mathrm{ml} l^{-1}$ for $10 \mathrm{~min}$. Samples were then immobilized on 1-mm 1.5\% agarose pads dissolved in LB medium and visualized using a Leica DMI4000B microscope fitted with a DFC365FX camera (Leica). The following Leica filter sets were used: N2.1 (for FM4-64), green fluorescent protein (for GFP), and A4 (for DAPI). Images were collected and processed using LAS AF 3.1 software (Leica).

\section{Results}

T7 RNA polymerase is superior over E. coli host polymerase in rescue of a deletion mutation gene

Previously, we had shown that the transcriptional slippage by T7 phage RNAP very effectively rescued single and double nucleotide indel mutations downstream of poly $(\mathrm{A} / \mathrm{T})$ regions, scattered over the mboIIM2 gene [16]. It was manifested by the production of an extra protein in addition to the truncated M2.MboII, i.e. the full-length M2.MboII methyltransferase, as a result of the indel-type mRNA edition. Subsequently, we wanted to compare the transcriptional slippage propensity of the two RNA polymerases distinct in terms of their origin and molecular structure, i.e. multisubunit one from 
the bacterial cell host $(E$. coli) and the single-subunit one from its parasite, bacteriophage T7 [53]. We constructed a plasmid (pBAD24/T7mboB $\Delta$ ) carrying the model mboIIM2 $\triangle A 356$ gene with the frameshift mutation $\triangle \mathrm{A} 356$ under independent control of both, $P_{\mathrm{araBAD}}$ and $\phi 10$ promoters $[45,54]$. Production of M2.MboII trans-frame variants in E. coli cell extracts was monitored by western blotting using anti-M2.MboII antibodies. As expected, after induction of T7 RNAP expression with IPTG, high level of both, the short and the full-length M2.MboII proteins were obtained regardless of the temperature conditions used during culturing of bacteria

$$
\begin{aligned}
& \text { a } \\
& \text { mbollM2 (WT) (349)..TTA.AAA. AAC.ACC.AAA.CTT.TTT.TTA.ATG...(375) } \\
& \text { mbollM2 } \triangle A 356 \quad \text {...TTA. AAA. ACA.CCA. AAC.TTT. TTT. TAA. TGG... }
\end{aligned}
$$
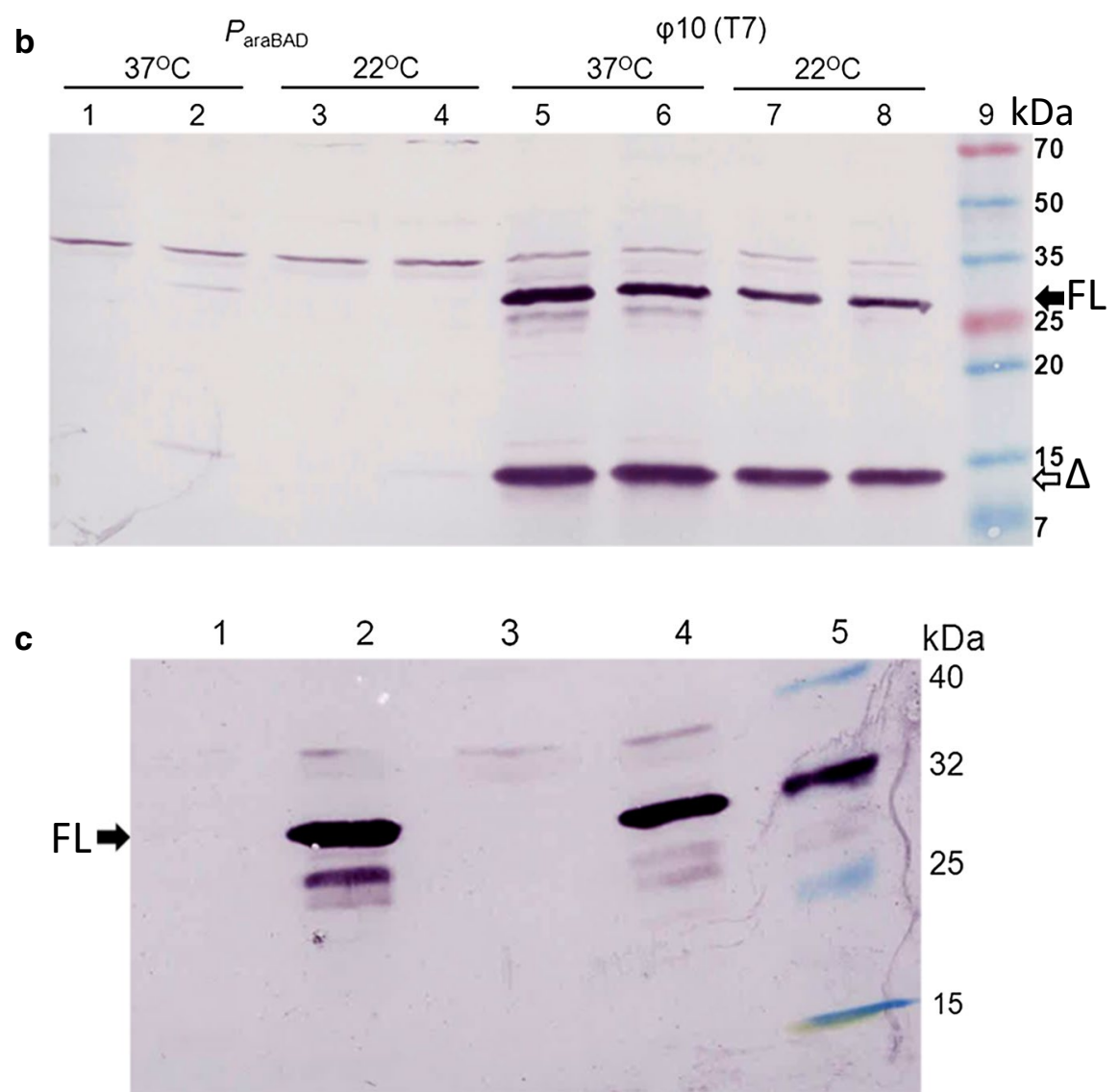

Fig. 1 Transcriptional slippage efficiency of E. coli and T7 phage RNA polymerases. a Details of the relevant sequence of the wild-type and mbol/M2 $\triangle A 356$ single nucleotide deletion genes. The position of the A356 nucleotide is marked in red. Premature stop codon is underlined. $\mathbf{b}$ Level of expression of the mbollM2 $\triangle A 356$ deletion mutant in frame 0 (short product [ $\triangle$ ] $14.5 \mathrm{kDa}$ ) and after insertional slippage (full length [FL] product WT-32 kDa), respectively, determined by western blotting. Expression was driven by E. coli RNAP (DH10B, lanes 1-4) or T7 RNAP (ER2566, lanes 5-8) from a gene located on PBAD24/T7mboB $\triangle$ plasmid at 37 and $22^{\circ} \mathrm{C}$, respectively. Induction of expression was carried out for $3 \mathrm{~h}$ with $0.1 \%$ L-arabinose (lanes 2 and 4) or 1 mM IPTG (lanes 6 and 8), respectively. Lanes 1, 3, 5 and 7 cell lysates from non-induced cultures. Equal amounts of total protein extracts normalized to $\mathrm{OD}_{600}$ were run on $12.5 \%$ SDS-PAGE, and immuno detected by using rabbit anti-M2.Mboll polyclonal antibody and secondary anti-rabbit-AP. Note, that "leaky" production of M2.Mboll proteins under non-inducing conditions (lanes 5 and 7) is due to lack of additional copy of lacl repressor gene on the pBAD24 backbone. Lane 9, molecular size prestained protein markers (EUR Poland). $\mathbf{c}$ Immunodetection of the wild-type mbollM2 gene product generated by the host (DH10B) or T7 RNAP (ER2566), respectively. Appropriate competent cells were transformed with pBAD24/T7mboWTlacl ${ }^{a}$ plasmid and the expression of the gene was induced for $2 \mathrm{~h}$ at $37^{\circ} \mathrm{C}$ with $0.1 \%$ L-arabinose/0.05 mM IPTG (lane 2) or 1 mM IPTG (lane 4), respectively. Lanes 1 and 3, cell lysates from non-induced cultures; lane 5, prestained protein markers, including purified M2.Mboll protein 
(Fig. 1a, lanes 6 and 8, respectively). In striking contrast, the production of both M2.MboII variant proteins by the host RNAP following arabinose induction was barely seen, reaching 40-fold lesser level than in the case of T7 RNAP specific expression (Fig. 1a, lanes 2 and 4, respectively). This was quite unexpected, since the $P_{\text {araBAD }}$ promoter is considered as one of the most powerful in $E$. coli. Indeed, the efficiency of the wild-type mboIIM2 gene expression was high in both cases (Fig. 1b, lanes 2 and 4, respectively). To exclude the possible influence of a spontaneous mutation which could lower the $P_{\text {araBAD }}$-dependent expression of the mboIIM2 $\triangle A 356$ carrying clones, we subcloned the "less-productive" gene from pBADmboB.4 plasmid into an intact pET24a vector under T7 promoter control, resulting in the pETremboB.4 construct. All randomly chosen recombinants exhibited high level production of truncated and full-length variants after induction of T7 RNAP (Additional file 1: Figure S1, lane 7).

\section{Intracistronic polarity effect during mbollM2 $\triangle A 356$ gene expression}

It is reasonable to hypothesize that appearance of a premature TAA stop codon in transcripts produced by $E$. coli RNAP during expression of mboIIM2 $\triangle A 356$ frameshifting mutant gene, would trigger ribosome stop followed by transcription and translation uncoupling [55-57]. Dramatic drop in mboIIM2 $\triangle A 356$ expression (Fig. 1a) could result from expanding gap between polymerase and the leading ribosome followed by mRNA decay and/ or terminator-dependent RNAP dissociation. This idea could indirectly supported by studies on expression of 377 - or 378-bp long truncated variants of the mboIIM2 gene which both relieved polarity effect (Fig. 2a, Additional file 1: Figure S2). In those cases we observed approximately eight- to tenfold increase in the production of M2.MboII short-variant for both mboIIM $2 \Delta 378$ and mboIIM2 $\triangle A 356 \Delta 377$ genes when compared to the full-length single deletion mutant gene (Fig. 2a, lane 4). In contrast to the host polymerase, T7 RNAP generated expression has been shown to manifest intrinsic resistance to the transcriptional polarity in the absence of T7-specific terminators [58-61]. Since expression of the mboIIM2 $\triangle A 356$ could only be 2.3 -fold increase by activating $\lambda$ phage $\mathrm{N} /$ nut $L$ antitermination system (Fig. 2a, lane 5) it is very likely, that $\mathrm{N}$ protein served here as a general elongation factor rather than as antiterminator of any intrinsic terminators [62].

To further investigate the polarity effect as a likely factor of observable expression differences, real time (RT) qPCR technique was used to determine the stability of WT and mutant mboIIM2 mRNA transcripts synthesized by the host RNAP. Values of the threshold cycle $\left(C_{t}\right)$ obtained for the particular sections of specific
mRNA normalized to external control cys $G$ gene [47] reflected relative abundance of the cDNA products located upstream and downstream of the premature TAA stop codon following the $\triangle \mathrm{A} 356$ frameshift mutation. The total RNA was isolated from strains bearing the native and mutant genes grown under inducing expression conditions (Fig. 2b). We used a set of five primer pairs designed to amplify 98-158 bp fragments of the target cDNA, located at both sides of the premature stop codon (Fig. 2b). We observed a dramatic decrease in the PCR product level generated from the downstream part of the gene in the case of deletion mutant variant mboIIM2 $\triangle A 356$, but not in the wild-type (Fig. 2b).

Next, RT-qPCR assay was performed to compare production level of mboIIM2 $\triangle A 356$ and the wild-type mRNA by activating of $\lambda$ phage $N / n u t L$ antitermination system (Fig. 2c). Several segments of mRNAs were analyzed, and we observed a two- to threefold improvement in detection of almost all products in case of WT mRNA, while in case of mutated gene the same refers only to the terminal part of the transcript molecule. However, experiments with a Rho-specific inhibitor, bicyclomycin [63] used at concentrations ranging from 5 to $100 \mu \mathrm{g} \mathrm{ml}^{-1}$ showed that production of the full-length M2.MboII protein from mboIIM2 $\triangle A 356$ was not affected (Additional file 1: Figure S3). Similarly, no positive effect in production of the full-length M2.MboII was observed when $E$. coli GJ6509 Rho $^{-}$strain [64] was used as the expression host (data not shown). In contrast, yield of the full-length mRNA increased ca. $30 \%$ at the expense of truncated transcript fraction of mboIIM2 $\triangle A 356$ in $\mathrm{CH} 1828$ rne-1 cells with conditionally inactivated RNase E (Fig. 2d, lane 3 vs. lane 4) [65]. Obviously, the uncovered mRNA fragment between ribosome and polymerase may become the target for endoribonucleic digestion. Consistently, full-length transcripts from the wild-type gene are stable in both RNase E phenotypes (Fig. 2d, lanes 1 and 2).

\section{Determination of the minimal sequence requirements for transcriptional slippage}

To determine how a length and kind of nucleotide forming the homopolymeric sequence affect the slippage event, we constructed set of poly $(\mathrm{A})$ and poly $(\mathrm{T})$ vectors with the $g f p$ reporter [42] for independent study of expression under the control of the arabinose and T7-phage promoters (Fig. 3, Additional file 1: Table S3). Each tested fusion gene contained slippery sequence attached upstream to the out-of-frame $g f p$ reporter $(-1$ or +1$)$. These fusions did not appear to have an intracistronic transcription polarity effect and enabled direct measurement of the transcriptional slippage ability [52]. All nucleotide sequence changes were created to obtain 


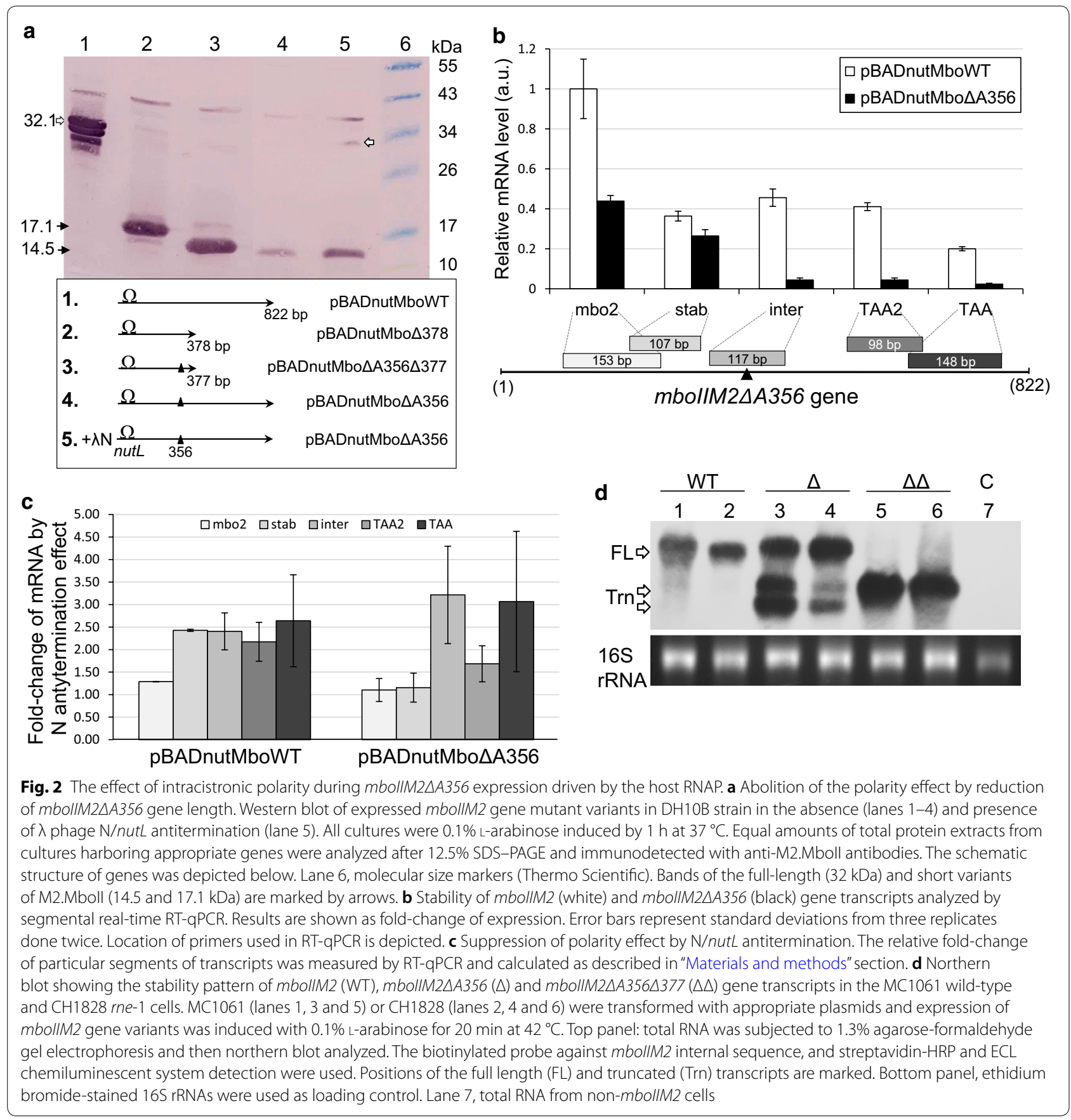

variants of runs with successively increased number of A or T nucleotides (Additional file 1: Table S3).

Bacterial cultures with plasmids carrying out-of-frame $g f p$ reporters were induced with either $1 \mathrm{mM} \mathrm{IPTG}$ (pETderivatives with $\mathrm{T} 7$ promoter) or $0.1 \%(6.7 \mathrm{mM}) \mathrm{L}$-arabinose (pBAD-derivatives with $\mathrm{P}_{\text {araBAD }}$ promoter), for $1 \mathrm{~h}$ at $37^{\circ} \mathrm{C}$. The concentration of the arabinose inductor was chosen to balance the sevenfold faster transcriptional rate of T7 RNAP [66]. Each time the obtained fluorescence levels of parallel cell lineages were referred to appropriate in-frame controls on either pET24a or pBAD24 backbone, and containing the same number of natural amino acids residues [52]. Our results (Fig. 3a-d) indicate strong ability of T7 RNAP to rescue poly(A) and poly $(\mathrm{T})$ frameshifted $g f p-1$ gene variants by nucleotide insertion, retained up to $90 \%$ and $50 \%$ of the in-frame control expression levels, respectively (Fig. 3a), while barely none fluorescence was detected in case of the host 


\section{(See figure on next page.)}

Fig. 3 Determination of the poly(A/T) minimal length requirements for transcriptional slippage. Relative fluorescence level of the rescued hybrid GFPs from the particular indel mutant gfp genes (Additional file 1: Table S3) measured after $1 \mathrm{~h}$ induction with $1 \mathrm{mM}$ IPTG (a) or 0.1\% L-arabinose (d). In-frame $g f p A_{4} 0, g f p A_{6} O, g f p T_{4} O$ and $g f p T_{6} O$ fusions were used as positive controls and were taken as $100 \%$. Error bars represent standard deviation from at least five independent determinations. Western blotting of the total extracts corresponding to the pET-based gfp genes in -1 frame (b) and +1 frame (c). Western blotting of the total extracts corresponding to the pBAD-based gfp genes in -1 frame (e) and +1 frame (f)

polymerase, with only $5 \%$ and $10 \%$ for poly $\left(\mathrm{T}_{7} / 8\right)$, with an opposite preference to the T7 enzyme (Fig. 3d). Remarkably, we show that T7 RNAP is potent to slip on such short homopolymers as three As and four Ts in a raw. In parallel, no detectable activity was identified for the host RNAP for homopolymers shorter than seven Ts and eight As, respectively (Fig. 3d).

Moreover, restoration of $g f p+1$ by T7 RNAP through deletion was significantly low (Fig. 3a), especially in case of poly(A)s where the efficiency of such an event never reached $20 \%$. In contrast, restoration by poly(T) nucleotides was at threefold higher efficiency, reaching over $60 \%$ in case of poly $\left(\mathrm{T}_{8}\right)$. In parallel, E. coli RNAP revealed higher preferences for poly $(\mathrm{T})$ erroneous deletions, giving $10 \%$ efficiency for poly $\left(\mathrm{T}_{8}\right)$ sequences and none for the poly(A) examined runs (Fig. 3d). Also, the fluorescence microscopy preparations of cells carrying the $g f p(A / T)-1$ fusions presented in Additional file 1: Figure S4 were consistent with the results of quantitative measurements. Generally, the longer the homopolymer length, the higher the level of rescue by insertion was observed. In contrast, for deletion slippage only poly(T) series apply to this rule.

All obtained results well correlated with immunodetection of the GFP hybrid protein levels from ER2566 and DH10B cell lysates (Fig. 3b, c, e, f, respectively).

\section{NGS mRNA analysis confirmed nucleotide bias of the host and T7 phage RNAPs in slippage induction}

Next, we tested whether observable differences in nucleotide type preferences are indeed significant. Recently NGS analysis of transcript indel polymorphism covering $375 \mathrm{nt}$ proximal part of mboIIM2 $\triangle A 356$ gene synthesized by the T7 RNAP was performed [16]. Now, to evaluate the extent of erroneous transcription led by $E$. coli RNAP analogous procedure was done. Comparative analysis showed four most dominant slippage sites, the same in case of both RNAPs (Additional file 1: Figure S5). However, the relative values of indel frequency presented variable amplitude of the slippage errors. In general, $E$. coli RNAP contributes to 8 times lower overall frequency of the nucleotide insertion and deletion $(0.0066 \%$ and $0.007 \%$, respectively) (Additional file 1: Figure S5, Additional file 1: Table S4). Insertion slippage level in the corresponding homopolymer runs was the highest for $\mathrm{T}_{6}(13$ nt) and $\mathrm{T}_{7}(364 \mathrm{nt})$ tracts $(0.82 \%$ and $0.75 \%$, respectively) and lower for $\mathrm{A}_{7}$ (279 nt) (0.39\%). Apparently, poly(T)type homopolymers induced higher insertion frequencies which correlates well with results obtained for expression of $g f p$ fusion mutants (Fig. 4). The most potent region for insertion generation by the T7 RNAP-poly $\left(\mathrm{A}_{5}\right)$ (351$355 \mathrm{nt})$, barely induces slippage in the case of the host RNAP (10.45\% vs. $0.062 \%)$. Furthermore, the poly $\left(\mathrm{T}_{7}\right)$ run (364-371 nt) appeared to be roughly half as efficient ( 0.75 vs $1.19 \%$, respectively). The combined frequency of insertions in both poly $(\mathrm{A})$ and poly $(\mathrm{T})$ regions, the key prerequisite of the A356 deletion mutation rescue of mboIIM2 $\triangle A 356$, is 14 times lower for the host RNAP than in case of the T7 enzyme (Additional file 1: Figure S5). Interestingly however, we did not notice any significant role in slippage induction for the $\mathrm{T}_{5}$ tract located between 314 and $318 \mathrm{nt}$ in both cases. It strongly suggests that it is not only the length of a homopolymer run, but also the context of the adjacent nucleotide sequence that is important for the incidence of transcriptional slippage $[16,26,67]$.

In order to evaluate the nucleotide-type preference/bias of $E$. coli RNAP for slippage in vivo, the mboIIM2 $\triangle A 356$ single deletion mutant gene with several changes in the homopolymer tracts important for rescue, were used (Fig. 4a). The site-specific nucleotide replacements systematically interrupted the continuity of the homopolymeric $A_{5}$ run (L-tract, 351-355 nt), and the R-tract, consisting of seven $\mathrm{T}$ (364-370 nt), upstream of the premature TAA stop codon in the gene (Fig. 4a, [16]). To better visualize the expression results we enhanced this process by $\lambda \mathrm{N}$ stimulation (Additional file 1: Figure S6). The $\Delta$ A356MutR2 mutant gene, with interrupted poly $\left(\mathrm{T}_{7}\right)$ sequence, resulted in a significantly decreased full-length methyltransferase production when compared to the $\Delta$ A356MutL3 mutant with interrupted poly $\left(\mathrm{A}_{5}\right)$ run (visible full-length protein production, Fig. 4b, top panel, lanes 5 and 6 vs. bottom panel, lanes 5 and 6). These results testify that A356 deletion mutation was bypassed mainly by $\mathrm{U}$ rather than $\mathrm{A}$ insertion and are in good agreement with indel mRNA polymorphism pattern for E. coli RNAP (Additional file 1: Figure S5) and, which is opposite to the T7 RNAP action [16]. Since no slippery sequences in this region remained in the $\triangle$ A356LMR6 mutant gene, no production of the fulllength protein was found and consequently no MboIIspecific methylation of DNA was detected (Fig. 4c). 


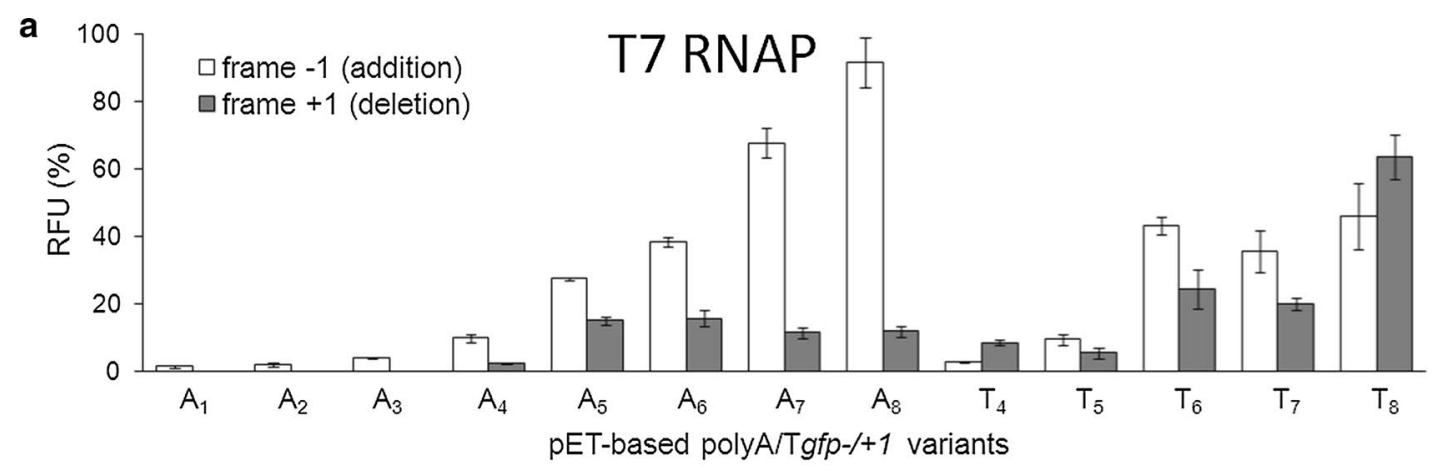

b

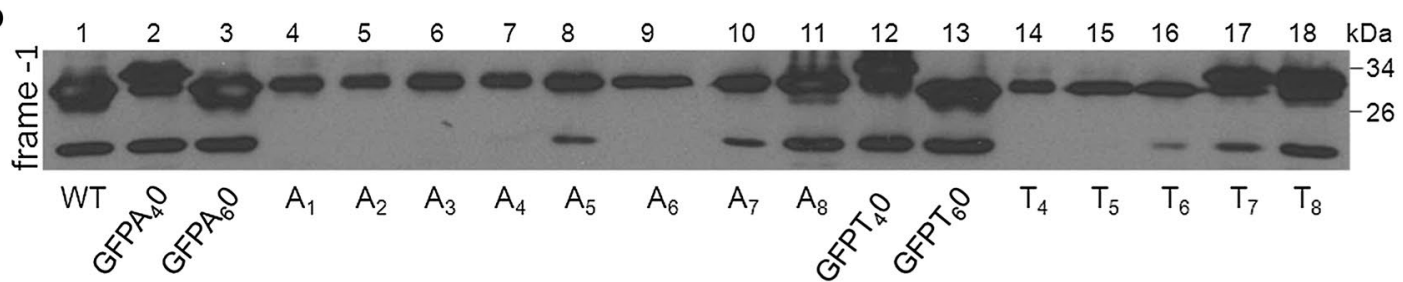

c

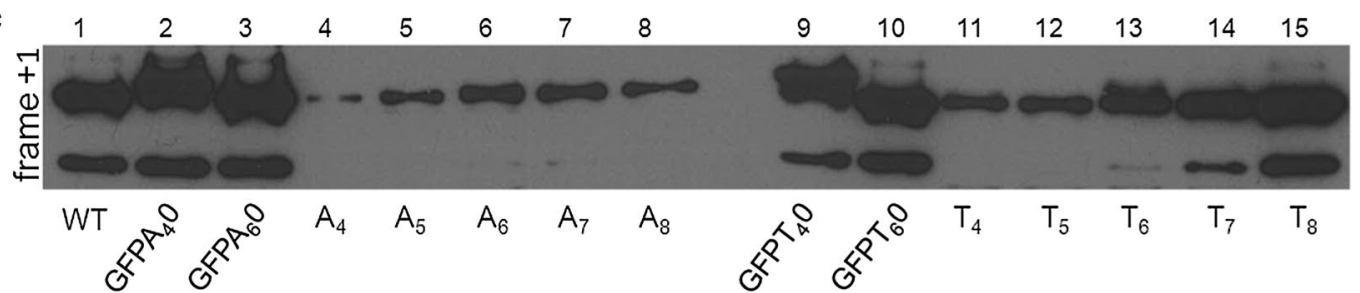

d
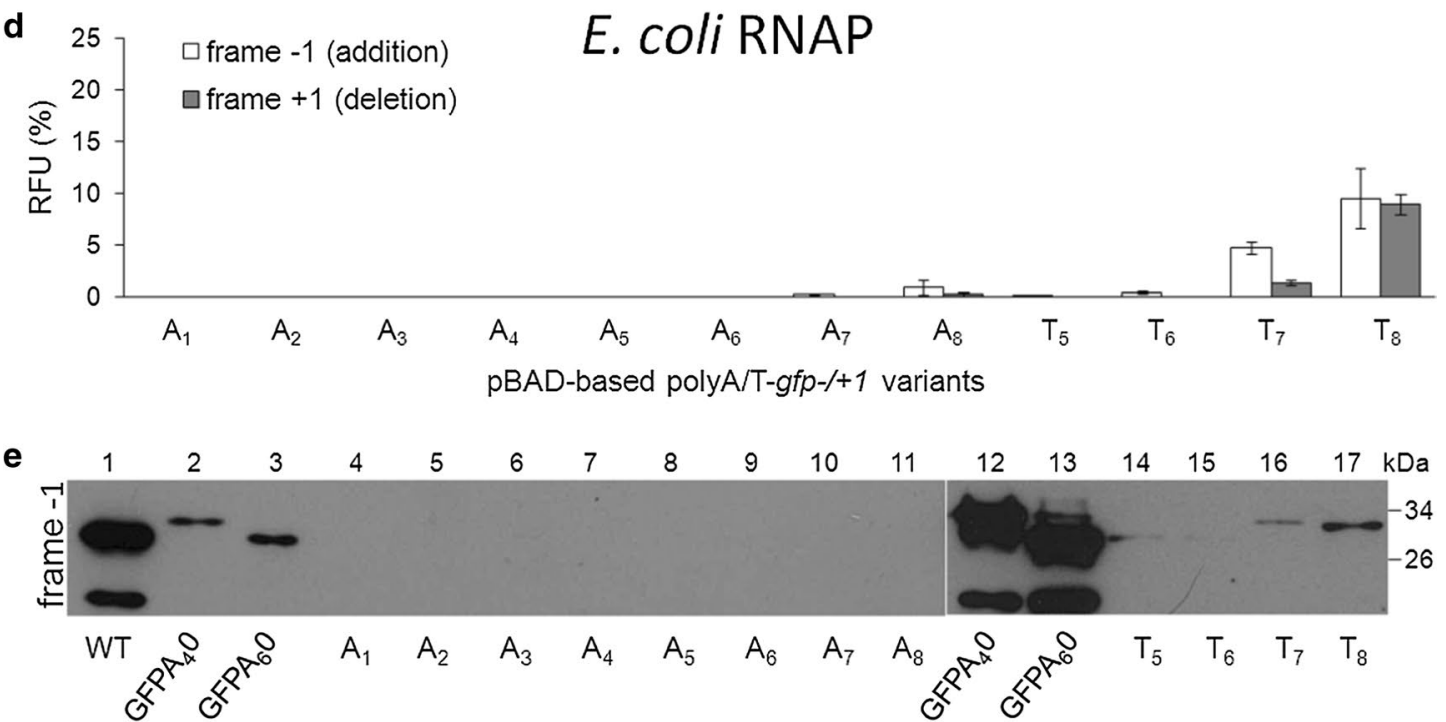

f

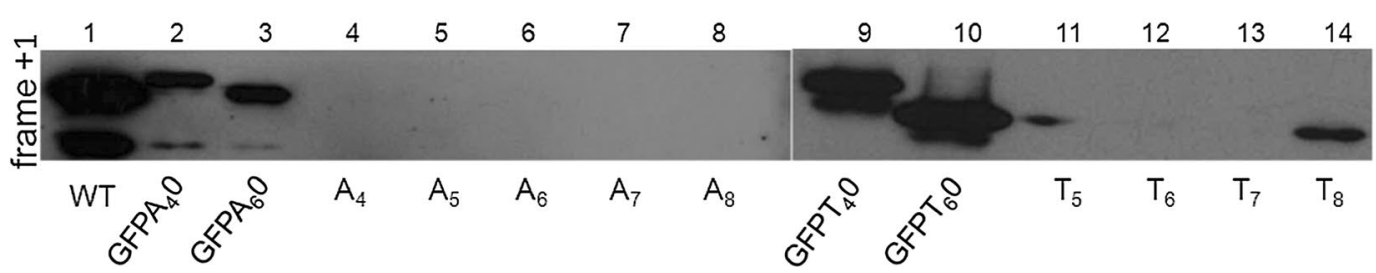


a

1. 348 nt 356 -tract

\section{R-tract}

Frame

3. ...ATT.TTA. AAA. ACA.CCA.AAC.TTC.TTC.TAA.TGG.ACA.CTT.ATC.TTT.GGA.ATA.G... -1

4. ...ATT.CTG.AAG.ACA.CCA.AAC.TTT. TTT.TAA.TGG.ACA.CTT.ATC.TTT.GGA.ATA.G...

5. ...ATT.CTG.AAG.ACA.CCA.AGC.TCT.TCT.TAA.TGG.ACA.CTT.ATC.TTT.GGA.ATA.G...

6. ...ATT.TTA. AAA. AAC.ACC.AAA.CTT.TTT. TTT. AAT.GGA.CAC.TTA.TCT.TTG.GAA.TAG. + +1

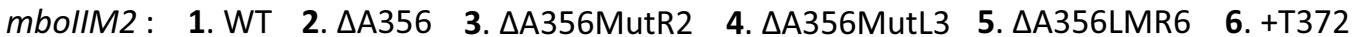

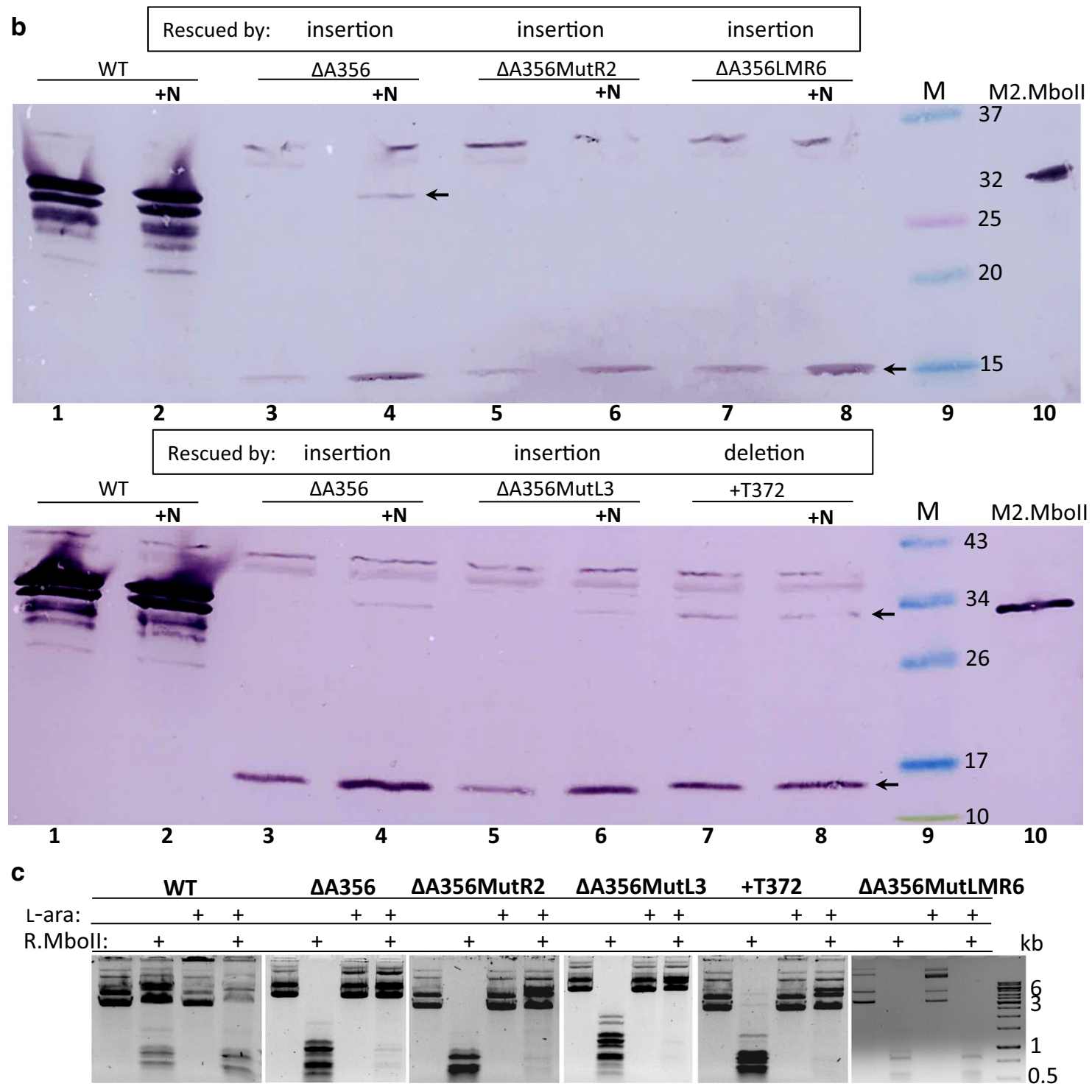

Fig. 4 Effect of $N /$ nutL antitermination on expression of $A / T$ homopolymers potent to bypass A356 deletion mutation of the mbol/M2 $\triangle A 356$ gene. a Details of sequence of the selected indel mutant genes (short names). Premature stop codons are underlined. T/A homopolymer runs are marked in red. Substituted nucleotides and the position of the A356 nucleotide are in bold. $\mathbf{b}$ Western blot of expressed gene mutants in DH10B strain in the absence or presence ( $\mathrm{N}$ ) of $\lambda$ phage $\mathrm{N} /$ nutL antitermination co-expression (both $0.1 \%$ L-arabinose induced for $1 \mathrm{~h}$ at $37^{\circ} \mathrm{C}$ ). Top and bottom panels: Equal amounts of total protein extracts from cultures harboring appropriate gene mutants were analyzed after $12.5 \%$ SDS-PAGE and immunodetection with anti-M2.Mboll antibodies. Lanes 9, molecular size markers (BioRad or Fermentas, respectively), lanes 10, M2.Mboll purified protein. Bands of full-length $(32 \mathrm{kDa})$ and short variant of M2.Mboll $(14.5 \mathrm{kDa})$ are pointed by arrows. c The relative protection level of the Mboll-specific sites against R.Mboll digestion in plasmids bearing the corresponding mbol/M2 indel mutants 
Western blot analysis of the protein extracts from cells expressing mboIIM2 indel variant genes indicated no reduction, but instead two- to threefold stimulatory effect of $\mathrm{N}$ protein on the production of both M2.MboII protein forms was observed (Fig. 4b). As reported previously, N-dependent inhibition of the host RNAP slippage preferentially affects nucleotide deletions [62]. We confirmed this in case of the +1 frameshift mutant + T372 $\left(\mathrm{T}_{8}, 364-372 \mathrm{bp}\right)$ expression. While in-frame short product synthesis was maintained on the same level under both conditions $\left(\mathrm{N}^{+} / \mathrm{N}^{-}\right)$, the full-length rescue product quantity was significantly reduced $(40 \%)$ in the presence of $\mathrm{N}$ (Fig. 4b, bottom panel, lane 8).

\section{Identity of the upstream and downstream bases adjacent to the slippery sequence impacts transcription slippage efficiency}

To study the influence of nucleotide type on induction of slippage, several $g f p-1$ and $g f p+1$ reporter genes were constructed (Additional file 1: Figure S7) varying in two nucleotides located directly upstream to the slipperyprone sequences: $g f p A_{5}$ and $g f p T_{5}$, respectively. Results for the tested di-nucleotides pairs were normalized to appropriate in-frame controls [52] and compared to the ones obtained for $T_{2} A_{5} \mp 1$ and $A_{2} T_{5} \mp 1$, respectively. In the case of $\mathrm{A}_{2} \mathrm{~T}_{5}-1$ template sequence, replacing the $5^{\prime}$-AA with CA, AC and GG did not affect slippage, while we observed $25 \%$ increase when AG and CC pairs were analyzed. Threefold decrease was shown in case of deletion slippage of $\mathrm{C}_{2} \mathrm{~T}_{5}+1$. In contrast, changing the primary TT of the $\mathrm{T}_{2} \mathrm{~A}_{5}-1$ motif to $\mathrm{TC}$ and $\mathrm{CC}$ resulted in $35 \%$ and $75 \%$ decrease in insertion-mode slippage, respectively. CT and GG substitutions gave no effect, and deletion slippage decreased by ca. $50 \%$ in case of CC pair. The fluorescence results were confirmed by immunoblotting of the GFP hybrid (Additional file 1: Figure S7c).

To study the effect of downstream located nucleotide, the primary $\mathrm{C}$ in $\mathrm{T}_{2} \mathrm{~A}_{5} \mathrm{C}-1$ and $\mathrm{A}_{2} \mathrm{~T}_{5} \mathrm{C}-1$ was replaced with $\mathrm{G}, \mathrm{T}$ or $\mathrm{A}$, respectively (Additional file 1: Figure S8). Results showed only a moderate impact of the $\mathrm{n}+1$ nucleotide. In case of $\mathrm{T}_{2} \mathrm{~A}_{5}-1$ series 2.2- and 2.7-fold decrease of insertion slippage was observed for $\mathrm{G}$ and $\mathrm{T}$ alterations. In contrast $\mathrm{C} \rightarrow \mathrm{A}$ substitution in $\mathrm{A}_{2} \mathrm{~T}_{5} \mathrm{C}-1$ did not result in any change and $50 \%$ increase was observed in case of $\mathrm{C} \rightarrow \mathrm{G}$.

In both cases the poly $\left(\mathrm{A}_{5}\right)$ homopolymers were more liable to the upstream and downstream nucleotide base changes.

\section{Discussion}

This study aimed for systematic investigation of transcriptional T7 phage and E. coli RNAPs slippage potential. Three parameters were analyzed: homopolymer length, template type, and frameshift direction preference. By using a set of out-of-frame $g f p$ reporter fusion genes we were able to monitor restoration of the native frame by a predominant single-nucleotide insertion or deletion events in upstream located $\mathrm{A} / \mathrm{T}$ mononucleotide tracts. We show that the minimum homopolymer length requirement for the productive in vivo transcriptional slippage by E. coli RNAP is $7 \mathrm{~T}_{\mathrm{s}}$ in a row (Fig. 3). In contrast, induction of effective slippage for T7 RNAP was possible with nucleotide tracts as short as either three As or four Ts (Fig. 3). Likewise, a remarkably high bypass of the frameshift mutations located in the proximal part of the $g f p$ gene was described in Bacillus subtilis cells [6]. Little inclination of the E. coli enzyme to slip is in agreement with earlier reports concerning the expression of lac $Z$ reporter fusions [37, 62, 68, 69] and transcriptomewide spectrum of indels analysis [40]. Accordingly, it was shown that detectable effect of indel mutation restoration required more than 7 As or Ts in a row. Our studies demonstrated a different slippage frequency pattern for the A/T homopolymer for phage and host RNAPs. Whereas an insertion slippage by T7 RNAP occurs preferentially at the poly(A) than poly(T) runs, strong bias for T nucleotides for the host RNAP is observed. At first glance, it is not surprising and could be explained by differences in the rU:dA structure stability (exceptionally unstable) when compared to the rA:dT duplexes [37, 70-72]. However, other causes may also rely upon various properties of the T7 phage RNAP, representing a single subunit class of enzymes, and multisubunit bacterial RNAP [73], even just because there are differences in the auxiliary factor dependency [74-77]. Recently reported interesting results shed some light on the complexity of this issue. As was shown, replacement of the Us tract with As in the T $\phi$ terminator allowed to reach half of the maximum termination efficient by T7 RNAP in vitro [26], which indicates its alternate transcriptional signals tolerance. Moreover, our study of indel frequency by NGS transcripts composition analysis of the mboIIM2 gene showed threefold increase of insertion type slippage over deletion, based on data from four active homopolymeric runs performed by the host RNAP, and its 6.5 times lower overall slippage effectiveness in comparison with the T7 enzyme (Fig. 4). It was further verified by in vivo experiments with T7 RNAP which revealed that backward slippage generated nucleotide insertion occurs 4-6 times more often than by deletion in the $5-8 \mathrm{nt}$ long runs (Fig. 3). This is in agreement with earlier suggestions that preference for transcriptional backward slippage is greater 
than forward slippage, at least in case of T7 RNAP [78]. What is more, insertion events in out-of-frame lac $Z$ mutants with a range between 7 and 11 adenine stretches were at least twice as much efficient as slippage by deletion [62]. We are aware that our results are just an estimate, not an absolute calculation, since as was shown elsewhere, in long homopolymers the slippage potential is more frequently divided into a "forward" and "backward" event differentiation [16, 37, 62]. In fact, slippage by enterobacterial RNAP was shown to occur in a run of 9 As or Ts and longer with variable directionality $[35,37$, $68,79,80]$. Both frameshifting types were detectable in a semi-synthetic $3 \mathrm{~A}^{\prime}$ reporter gene containing $\mathrm{T}_{9}$ slippery sequence, with increased forward (base insertion) over backward frameshifting, in a growth phase dependent manner [81]. Likewise, a $\mathrm{T}_{9}$-run in the template strand of dnaX gene mRNA sequence of Thermus thermophilus was found to induce both -1 and +1 frameshift in E. coli, with predominance of multiple insertions [30, 82]. Similar observation concerns E. coli lac $Z$ gene $\left(\mathrm{A}_{11}\right)$ [37], spa13 $\left(\mathrm{A}_{10}\right)$ and mxiE $\left(\mathrm{T}_{9}\right)$ genes of Shigella flexnerii $[80$, 83], and the mur gene family $\left(\mathrm{A}_{10}\right)$ of Buchnera aphidicola [35] and also tssM of Citrobacter rodentium [79]. Interestingly, yeast RNAP II and $E$. coli RNAP exhibited the opposite slippage directionality in the $\mathrm{A}_{11}$-tract, weak insertion propensity and deletion predominance, respectively, in an experiment performed under the same transcription in vitro conditions [84]. All of the above examples suggested variable and vicinity contextdependent ability of RNAP to make indel errors [68]. In fact, we have shown that identity of nucleotides upstream and downstream of the slippage-prone sequence could moderately change the slippage efficiency, ranging from $25 \%$ to almost 1.5-fold (Additional file 1: Figures S7 and S8). This is likely related to the fact that the rate of misincorporation by misalignment is significantly increased when more than one base pair downstream of the RNAP active site in DNA duplex is melted [85]. To some extent it can be suppressed by stabilizing action of $\lambda \mathrm{N}$ antitermination protein $[62,86]$. Obviously, we cannot exclude the involvement of much broader nucleotide context of upstream sequences that could form a secondary structure which could negatively/positively impact slippage. For instance, Penno and collaborators [11] showed realignment in two directions at the stem-loop RNA, stimulating slippage at $\mathrm{T}_{6}-\mathrm{T}_{9}$ runs with predominance of the base deletion events and several-fold decrease in slippage by replacement of the penta-nucleotide segment in the upstream sequence $[68,80]$.

Although the two examined enzymes represent quite different classes of polymerases, the length of the RNA:DNA hybrid and size of transcriptional bubble are conserved between single and multisubunit RNAPs and undergo intrinsic endonucleolytic regulation, at least in case of the last one [87]. A stable 8-10 bp RNA-DNA hybrid in the transcription elongation complex is essential for keeping the RNA 3'terminus engaged with active site of $E$. coli RNAP in register with the template strand [88, 89]. Protein-nucleic acid interactions upstream and downstream of the hybrid region play primary role in holding together all components of the polymerase elongation complex $[89,90]$. As was shown, increased slippage phenotype in some rpoB mutants that cluster along the RNA strand of the hybrid, involved transient separation of the RNA and DNA template strand in the elongation complex and resulted in the loss of transcription register $[69,84,91]$. However, tight contact of the RNAP with RNA:DNA hybrid is limited to the first 2-3 3'-proximal bp of the heteroduplex whose base pairs complementarity is sensed and recognized [92, 93]. Destabilization in this part of the RNA:DNA hybrid triggers realignment and promotes slippage.

Besides that, it is also reasonable to consider observed differences in the light of proofreading process involvement and participation of the auxiliary factors which determine non-uniform mechanism of fidelity among the host and phage RNAPs [94]. Importantly, T7 RNAP neither exhibits intrinsic proofreading activity [95] nor mRNA elongation process involves transcriptional proteins, in contrast to the host polymerase [5, 74-77]. This is especially evident in the case of the mboIIM2 $\triangle A 356$ single deletion mutant gene expression. We demonstrated a 40 times greater difference in ratio of $\Delta \mathrm{A} 356$ mutant corrective slippage, as well as overall expression of the in-frame part of the gene in favor of the T7 RNAP (Fig. 1). That result was in contrast to $g f p$ fusions with the proximal located out-of-frame segments. Such discrepancy in effectiveness is due to strong transcriptional polarity which the host RNAP transcription process was subjected to. Tight coupling between leading ribosome and RNAP plays a central role in controlling gene expression, mainly by preventing nascent terminator hairpin formation and binding of the transcription termination Rho global regulator [96]. Moreover, mRNA translating ribosomes modulate formation of nascent RNA structure [97], block RNAP backtracking and protect mRNA from RNase degradation [65, 66, 98]. Uncoupling between transcription and translation causes RNAP to adopt at non-productive state [55], as well as elongation complex disruption and dissociation within coding sequences [96, 99, 100]. Consequently, accelerated mRNA decay [101] and degradation of truncated polypeptide take place $[102,103]$. Here, we showed greater instability of the mboIIM2 $\triangle A 356$ full-length mRNA transcript (Fig. 2d) as a result of premature translation termination. Comparative analysis of the mboIIM2 transcript segments by 
real-time RT-qPCR confirmed its terminal part instability (Fig. 2b). Since active translation can protect the mRNA against an attack of cellular endoribonucleases, we investigated the role of RNaseE in mboIIM2 $\triangle A 356$ mRNA degradation using E. coli $\mathrm{CH} 1828$ strain carrying the rne-1 thermosensitive mutation [65]. RNase E is known to initiate the decay of most individual mRNAs by internal cleavage in the single-stranded untranslated region rich in AU residues [104]. We showed that expression of the mboIIM2 $\triangle A 356$ gene under RNase E deficient conditions significantly reduced degradation of the fulllength transcript (Fig. 2d). N/nutL antitermination system, also known as a slippage inhibitor in the very long A/T tracts [62], only partially suppressed the observed transcription polarity effect (Fig. 2c). However, deletion of the fragment of gene upstream of the A356 frameshifting site almost completely abolished it (Fig. 2a). We showed that $\mathrm{N}$ did not act as an actual slippage reducer in this case, but rather as a factor stimulating elongation rate of RNAP by pause elimination [62, 105, 106]. Further experiments showed positive stimulation of transcription in both frames $(-11 /+1)$, when $\mathrm{A} / \mathrm{T}$ homopolymers were shorter than 8 nucleotides (Fig. 4). An earlier study had shown [62] that $\mathrm{N}$ served more significantly as an inhibitor of slippage which occurred via nucleotide deletion. We found this to be the case for the $+\mathrm{T} 372$ insertion mutant mboIIM2 gene with eight consecutive $\mathrm{T}$ (364-372 bp) (Fig. 4b, bottom panel). Interestingly, in the absence of the nutL sequence, the $\mathrm{N}$ protein inhibits overall expression process in both, the native and deletion mutant gene (Additional file 1: Figure S6a, lanes 5 and 11), consistent with the effects described elsewhere [57, 107-109]. Since the presence of GreA and GreB auxiliary factors increases fidelity, their contribution to the slippage process cannot be excluded. This idea was supported earlier by a reporter assay in $\triangle$ greAB cells where shift-prone $\mathrm{A}_{9}$ tract within lacI gene resulted in a several dozen times increased frameshift frequency over wildtype, however, transcription errors were not measured directly $[5,33]$. In fact, to induce slippage, E. coli RNAP requires very long stretches of monotonous $A / T$ tracts which are rather rarely found in the chromosome [110]. Especially, one might assume that the mechanism of indel error formation by flipping-out of a base one strand of the nascent RNA:DNA hybrid gives different results than simple nucleotide misincorporation, because the nucleotide change is quantitative and no qualitative. Misincorporation does not allow to form the correct base pairing between improper NTP with the template DNA, and such distortion impairs further mRNA extension and the enzyme translocation. Since homopolymeric indel nucleotide is always cognate and matched to the $i+1$ site of the template strand, it presumably neither perturbs the $3^{\prime}$ end of the hybrid stability nor enforces backtracked pauses of the enzyme. Generated errors can possibly be corrected by slow intrinsic proofreading rather than stimulating action of Gre/DskA factors, either in enhancement of the cleavage activity or in restart of the backtracked RNAP [111]; Roghanian et al. [75]; Satory et al. [76, 112]. For this reason, GreAB action might have a rather limited impact on the slippage process. Indeed, we tested expression level of the $g f p T_{8}-1$ variant generated by $E$. coli host RNAP in the WT as well as in its isogenic $\triangle$ gre $A B$ strain and we did not find an increase in the rescue of GFP production level (Additional file 1: Figure S9). We could not test the polyA homopolymeric sequence due to slippage occurring below the level of detection. Recently, several reports did not confirm significant effects on transcriptional indel rates as a result of the absence of Gre factors, with the exception of preponderance of $\mathrm{G} \rightarrow \mathrm{A}$ misincorporation in mutants lacking GreA [111-114].

In conclusion, RNAP propensity to slippage involves trade-offs between accuracy, speed and processivity of transcription. Viral T7 RNAP manifests far greater inclinations to the transcriptional slippage than $E$. coli RNAP. This phenotypic variability possibly plays an important role in driving bacteriophage adaptation and therefore could be considered as beneficial in that case. However, from biotechnological and experimental point of view it creates some problems. High level of frameshift errors in nascent RNA results in expression and accumulation of misfunctioning trunckated proteins. This could be detrimental for global cell physiology by metabolic burden and necessity to launch energy consuming "cleansing" mechanisms as a response to proteotoxic stress, as well as loss of control over the quality of protein preparations. Taking all above into consideration, this strongly argues for employing bacterial expression systems stocked with proofreading mechanism as a recommended solution, especially when expression profile of an indel mutated gene must be unambiguously investigated. However, high poly(A)-based backward slippage propensity of T7 RNAP can be utilized in case of two or more combined genes expression as a new possibility for transcription downregulation of a selective indel gene, to obtain desired protein amounts.

\section{Additional file}

Additional file 1. Additional Tables S1-S4, Figures S1-S9.

Authors' contributions

MS, DK and EW conceived and designed the research. DK,EW, KW and MS performed the experiments, analyzed the data. EW and MS wrote the manuscript. 
DK and EW contributed equally to this work. All authors read and approved the final manuscript.

\section{Acknowledgements}

We wish to thank Monika Szadkowska for their technical assistance. We wish to express special thanks to Kasia Potrykus (University of Gdansk) for critical reading of the work.

\section{Competing interests}

The authors declare that they have no competing interests.

\section{Availability of data and materials}

All data and materials will be available upon request.

\section{Consent for publication}

Not applicable.

\section{Ethics approval and consent to participate}

Not applicable.

\section{Funding}

This work was supported by the National Science Centre (Poland) (Grants: DEC-2012/07/B/NZ2/01782 to M.S., and DEC-2017/01/X/NZ1/01922 to E.W.) and University of Gdansk (Grant 583-L135-B151-18 to D.K.)

\section{Publisher's Note}

Springer Nature remains neutral with regard to jurisdictional claims in published maps and institutional affiliations.

Received: 26 September 2018 Accepted: 19 November 2018 Published online: 24 November 2018

\section{References}

1. Elowitz MB, Levine AJ, Siggia ED, Swain PS. Stochastic gene expression in a single cell. Science. 2002;297:1183-6.

2. Golding I, Paulsson J, Zawilski SM, Cox EC. Real-time kinetics of gene activity in individual bacteria. Cell. 2005;123:1025-36.

3. Swain PS, Elowitz MB, Siggia ED. Intrinsic and extrinsic contributions to stochasticity in gene expression. Proc Natl Acad Sci USA. 2002;99:12795-800.

4. Raj A, van Oudenaarden A. Nature, nurture, or chance: stochastic gene expression and its consequences. Cell. 2008;135:216-26.

5. Gordon AJ, Halliday JA, Blankschien MD, Burns PA, Yatagai F, Herman C. Transcriptional infidelity promotes heritable phenotypic change in a bistable gene network. PLoS Biol. 2009;7:e44

6. Meyerovich M, Mamou G, Ben-Yehuda S. Visualizing high error levels during gene expression in living bacterial cells. Proc Natl Acad Sci USA. 2010;107:11543-8.

7. Atkins JF, Loughran G, Bhatt PR, Firth AE, Baranov PV. Ribosomal frameshifting and transcriptional slippage: from genetic steganography and cryptography to adventitious use. Nucleic Acids Res. 2016:44:7007-78.

8. Casadesús J, Low D. Epigenetic gene regulation in the bacterial world. Microbiol Mol Biol Rev. 2006;70:830-56.

9. Atkins JF, Gesteland RF. Recoding: expansion of decoding rules enriches gene expression. Nucleic acids and molecular biology, vol. 24. Berlin: Springer; 2010.

10. Gordon AJ, Satory D, Halliday JA, Herman C. Lost in transcription: transient errors in information transfer. Curr Opin Microbiol. 2015;24:80-7.

11. Penno C, Sharma V, Coakley A, O'Connell Motherway M, van Sinderen D, Lubkowska L, Kireeva ML, Kashlev M, Baranov PV, Atkins JF. Productive mRNA stem loop-mediated transcriptional slippage: crucial features in common with intrinsic terminators. Proc Natl Acad Sci USA. 2015;112:E1984-93.

12. Satory D, Gordon AJ, Halliday JA, Herman C. Epigenetic switches: can infidelity govern fate in microbes? Curr Opin Microbiol. 2011;14:212-7.
13. Anikin M, Molodtsov V, Temiakov D, McAllister WT. Transcript slippage and recoding. In: Atkins JF, Gesteland RF, editors. Recoding: expansion of decoding rules enriches gene expression, vol. 24. New York: Springer; 2010.

14. Sharma V, Firth AE, Antonov I, Fayet O, Atkins JF, Borodovsky M, Baranov PV. A pilot study of bacterial genes with disrupted ORFs reveals a surprising profusion of protein sequence recoding mediated by ribosomal frameshifting and transcriptional realignment. Mol Biol Evol. 2011;28:3195-211.

15. Turnbough CL. Regulation of gene expression by reiterative transcription. Curr Opin Microbiol. 2011;14:142-7.

16. Wons E, Furmanek-Blaszk B, Sektas M. RNA editing by T7 RNA polymerase bypasses InDel mutations causing unexpected phenotypic changes. Nucleic Acids Res. 2015:43:3950-63.

17. Banavali NK. Partial base flipping is sufficient for strand slippage near DNA duplex termini. J Am Chem Soc. 2013;135:8274-82.

18. Neher RA, Gerland U. Dynamics of force-induced DNA slippage. Phys Rev Lett. 2004;93:198102.

19. Arnott S, Chandrasekaran R, Hall IH, Puigjaner LC. Heteronomous DNA. Nucleic Acids Res. 1983;11:4141-55

20. Klug A, Jack A, Viswamitra MA, Kennard O, Shakked Z, Steitz TA. A hypothesis on a specific sequence-dependent conformation of DNA and its relation to the binding of the lac-repressor protein. J Mol Biol. 1979;131:669-80.

21. Nelson HC, Finch JT, Luisi BF, Klug A. The structure of an oligo(dA).oligo(dT) tract and its biological implications. Nature. 1987;330:221-6.

22. Rhodes D, Klug A. Sequence-dependent helical periodicity of DNA. Nature. 1981;292:378-80

23. Yoon C, Privé GG, Goodsell DS, Dickerson RE. Structure of an alternating-B DNA helix and its relationship to A-tract DNA. Proc Natl Acad Sci USA. 1988;85:6332-6.

24. Kvaratskhelia M, Budihas SR, Le Grice SF. Pre-existing distortions in nucleic acid structure aid polypurine tract selection by HIV-1 reverse transcriptase. J Biol Chem. 2002;277:16689-96.

25. Sarafianos SG, Das K, Tantillo C, Clark AD, Ding J, Whitcomb JM, Boyer PL, Hughes SH, Arnold E. Crystal structure of HIV-1 reverse transcriptase in complex with a polypurine tract RNA:DNA. EMBO J. 2001;20:1449-61.

26. Molodtsov V, Anikin M, McAllister WT. The presence of an RNA:DNA hybrid that is prone to slippage promotes termination by T7 RNA polymerase. J Mol Biol. 2014;426:3095-107.

27. Kashkina E, Anikin M, Brueckner F, Pomerantz RT, McAllister WT, Cramer P, Temiakov D. Template misalignment in multisubunit RNA polymerases and transcription fidelity. Mol Cell. 2006;24:257-66.

28. Pomerantz RT, Temiakov D, Anikin M, Vassylyev DG, McAllister WT. A mechanism of nucleotide misincorporation during transcription due to template-strand misalignment. Mol Cell. 2006;24:245-55.

29. Tsuchihashi Z, Brown PO. Sequence requirements for efficient translational frameshifting in the Escherichia coli dnaX gene and the role of an unstable interaction between tRNA(Lys) and an AAG lysine codon. Genes Dev. 1992;6:511-9.

30. Larsen B, Wills NM, Nelson C, Atkins JF, Gesteland RF. Nonlinearity in genetic decoding: homologous DNA replicase genes use alternatives of transcriptional slippage or translational frameshifting. Proc Natl Acad Sci USA. 2000;97:1683-8.

31. Turnbough CL, Switzer RL. Regulation of pyrimidine biosynthetic gene expression in bacteria: repression without repressors. Microbiol Mol Biol Rev. 2008;72:266-300.

32. Baranov PV, Hammer AW, Zhou J, Gesteland RF, Atkins JF. Transcriptional slippage in bacteria: distribution in sequenced genomes and utilization in IS element gene expression. Genome Biol. 2005;6:R25.

33. Gordon AJ, Satory D, Halliday JA, Herman C. Heritable change caused by transient transcription errors. PLoS Genet. 2013;9:e1003595.

34. Rockah-Shmuel L, Tóth-Petróczy Á, Sela A, Wurtzel O, Sorek R, Tawfik DS. Correlated occurrence and bypass of frame-shifting insertion-deletions (InDels) to give functional proteins. PLoS Genet. 2013;9:e1003882.

35. Tamas I, Wernegreen JJ, Nystedt B, Kauppinen SN, Darby AC, GomezValero L, Lundin D, Poole AM, Andersson SG. Endosymbiont gene functions impaired and rescued by polymerase infidelity at poly(A) tracts. Proc Natl Acad Sci USA. 2008;105:14934-9. 
36. Wernegreen JJ, Kauppinen SN, Degnan PH. Slip into something more functional: selection maintains ancient frameshifts in homopolymeric sequences. Mol Biol Evol. 2010;27:833-9.

37. Wagner LA, Weiss RB, Driscoll R, Dunn DS, Gesteland RF. Transcriptional slippage occurs during elongation at runs of adenine or thymine in Escherichia coli. Nucleic Acids Res. 1990;18:3529-35.

38. Groebe DR, Uhlenbeck OC. Characterization of RNA hairpin loop stability. Nucleic Acids Res. 1988;16:11725-35.

39. Xiong XF, Reznikoff WS. Transcriptional slippage during the transcription initiation process at a mutant lac promoter in vivo. J Mol Biol. 1993;231:569-80.

40. Traverse CC, Ochman H. Genome-wide spectra of transcription insertions and deletions reveal that slippage depends on RNA:DNA hybrid complementarity. MBio. 2017;8:e01230.

41. Murakami KS. Structural biology of bacterial RNA polymerase. Biomolecules. 2015;5:848-64.

42. Miller WG, Lindow SE. An improved GFP cloning cassette designed for prokaryotic transcriptional fusions. Gene. 1997;191:149-53.

43. Sambrook J, Fritsch EF, Maniatis T. Molecular cloning. A laboratory manual. Cold Spring Harbor: Cold Spring Harbor Laboratory Press; 1989

44. Vinella D, Potrykus K, Murphy $H$, Cashel M. Effects on growth by changes of the balance between GreA, GreB, and DksA suggest mutual competition and functional redundancy in Escherichia coli. J Bacteriol. 2012;194:261-73.

45. Guzman LM, Belin D, Carson MJ, Beckwith J. Tight regulation, modulation, and high-level expression by vectors containing the arabinose PBAD promoter. J Bacteriol. 1995;177:4121-30.

46. Furmanek-Blaszk B, Boratynski R, Zolcinska N, Sektas M. M1.Mboll and M2.Mboll type IIS methyltransferases: different specificities, the same target. Microbiology. 2009;155:1111-21.

47. Zhou K, Zhou L, Lim Q, Zou R, Stephanopoulos G, Too HP. Novel reference genes for quantifying transcriptional responses of Escherichia coli to protein overexpression by quantitative PCR. BMC Mol Biol. 2011;12:18.

48. Pfaffl MW. A new mathematical model for relative quantification in real-time RT-PCR. Nucleic Acids Res. 2001;29:e45.

49. Furmanek B, Sektas M, Wons E, Kaczorowski T. Molecular characterization of the DNA methyltransferase M1.Ncul from Neisseria cuniculi ATCC 14688. Res Microbiol. 2007;158:164-74.

50. Dopf J, Horiagon TM. Deletion mapping of the Aequorea victoria green fluorescent protein. Gene. 1996;173:39-44.

51. Li X, Zhang G, Ngo N, Zhao X, Kain SR, Huang CC. Deletions of the Aequorea victoria green fluorescent protein define the minimal domain required for fluorescence. J Biol Chem. 1997;272:28545-9.

52. Wons E, Koscielniak D, Szadkowska M, Sektas M. Evaluation of GFP reporter utility for analysis of transcriptional slippage during gene expression. Microb Cell Fact. 2018;17:150.

53. McAllister WT, Raskin CA. The phage RNA polymerases are related to DNA polymerases and reverse transcriptases. Mol Microbiol. 1993:10:1-6.

54. Tabor S, Richardson CC. A bacteriophage T7 RNA polymerase/promoter system for controlled exclusive expression of specific genes. Proc Natl Acad Sci USA. 1985;82:1074-8.

55. Proshkin S, Rahmouni AR, Mironov A, Nudler E. Cooperation between translating ribosomes and RNA polymerase in transcription elongation. Science. 2010;328:504-8.

56. de Smit MH, Verlaan PW, van Duin J, Pleij CW. Intracistronic transcriptional polarity enhances translational repression: a new role for Rho. Mol Microbiol. 2008;69:1278-89.

57. Stanssens P, Remaut E, Fiers W. Inefficient translation initiation causes premature transcription termination in the lacZ gene. Cell. 1986;44:711-8.

58. Chevrier-Miller M, Jacques N, Raibaud O, Dreyfus M. Transcription of single-copy hybrid lacZ genes by T7 RNA polymerase in Escherichia coli: mRNA synthesis and degradation can be uncoupled from translation. Nucleic Acids Res. 1990;18:5787-92.

59. Lopez PJ, lost I, Dreyfus M. The use of a tRNA as a transcriptional reporter: the T7 late promoter is extremely efficient in Escherichia coli but its transcripts are poorly expressed. Nucleic Acids Res. 1994;22:2434
60. Pasman Z, von Hippel PH. Regulation of rho-dependent transcription termination by NusG is specific to the Escherichia coli elongation complex. Biochemistry. 2000;39:5573-85.

61. Studier FW. Bacteriophage T7. Science. 1972;176:367-76.

62. Parks AR, Court C, Lubkowska L, Jin DJ, Kashlev M, Court DL. Bacteriophage $\lambda$ N protein inhibits transcription slippage by Escherichia coli RNA polymerase. Nucleic Acids Res. 2014;42:5823-9.

63. Zwiefka A, Kohn H, Widger WR. Transcription termination factor rho: the site of bicyclomycin inhibition in Escherichia coli. Biochemistry. 1993;32:3564-70.

64. Saxena S, Gowrishankar J. Modulation of Rho-dependent transcription termination in Escherichia coli by the H-NS family of proteins. J Bacteriol. 2011;193:3832-41.

65. Joyce SA, Dreyfus M. In the absence of translation, RNase E can bypass 5' mRNA stabilizers in Escherichia coli. J Mol Biol. 1998;282:241-54.

66. lost I, Guillerez J, Dreyfus M. Bacteriophage T7 RNA polymerase travels far ahead of ribosomes in vivo. J Bacteriol. 1992;174:619-22.

67. Komissarova N, Becker J, Solter S, Kireeva M, Kashlev M. Shortening of RNA:DNA hybrid in the elongation complex of RNA polymerase is a prerequisite for transcription termination. Mol Cell. 2002;10:1151-62.

68. Penno C, Sansonetti P, Parsot C. Frameshifting by transcriptional slippage is involved in production of MxiE, the transcription activator regulated by the activity of the type III secretion apparatus in Shigella flexneri. Mol Microbiol. 2005;56:204-14.

69. Zhou YN, Lubkowska L, Hui M, Court C, Chen S, Court DL, Strathern J, Jin DJ, Kashlev M. Isolation and characterization of RNA polymerase rpoB mutations that alter transcription slippage during elongation in Escherichia coli. J Biol Chem. 2013;288:2700-10.

70. Chamberlin MJ. Comparative properties of DNA, RNA, and hybrid homopolymer pairs. Fed Proc. 1965;24:1446-57.

71. Huang Y, Chen C, Russu IM. Dynamics and stability of individual base pairs in two homologous RNA-DNA hybrids. Biochemistry. 2009;48:3988-97.

72. Martin FH, Tinoco I. DNA-RNA hybrid duplexes containing oligo(dA:rU) sequences are exceptionally unstable and may facilitate termination of transcription. Nucleic Acids Res. 1980;8:2295-9.

73. Steitz TA. The structural basis of the transition from initiation to elongation phases of transcription, as well as translocation and strand separation, by T7 RNA polymerase. Curr Opin Struct Biol. 2004;14:4-9.

74. Borukhov S, Lee J, Laptenko O. Bacterial transcription elongation factors: new insights into molecular mechanism of action. Mol Microbiol. 2005:55:1315-24

75. Roghanian M, Zenkin N, Yuzenkova Y. Bacterial global regulators DksA/ppGpp increase fidelity of transcription. Nucleic Acids Res. 2015;43:1529-36

76. Satory D, Gordon AJ, Wang M, Halliday JA, Golding I, Herman C. DksA involvement in transcription fidelity buffers stochastic epigenetic change. Nucleic Acids Res. 2015:43:10190-9.

77. Zhang Y, Mooney RA, Grass JA, Sivaramakrishnan P, Herman C, Landick R, Wang JD. DksA guards elongating RNA polymerase against ribosome-stalling-induced arrest. Mol Cell. 2014;53:766-78.

78. Bonner G, Lafer EM, Sousa R. Characterization of a set of T7 RNA polymerase active site mutants. J Biol Chem. 1994;269:25120-8.

79. Gueguen E, Wills NM, Atkins JF, Cascales E. Transcriptional frameshifting rescues Citrobacter rodentium type $\mathrm{VI}$ secretion by the production of two length variants from the prematurely interrupted tssM gene. PLoS Genet. 2014;10:e1004869.

80. Penno C, Hachani A, Biskri L, Sansonetti P, Allaoui A, Parsot C. Transcriptional slippage controls production of type III secretion apparatus components in Shigella flexneri. Mol Microbiol. 2006;62:1460-8.

81. Wenthzel AM, Stancek M, Isaksson LA. Growth phase dependent stop codon readthrough and shift of translation reading frame in Escherichia coli. FEBS Lett. 1998;421:237-42.

82. Yurieva O, Skangalis M, Kuriyan J, O'Donnell M. Thermus thermophilis dnaX homolog encoding gamma- and tau-like proteins of the chromosomal replicase. J Biol Chem. 1997;272:27131-9.

83. Penno C, Parsot C. Transcriptional slippage in mxiE controls transcription and translation of the downstream mxiD gene, which encodes a component of the Shigella flexneri type III secretion apparatus. J Bacteriol. 2006;188:1196-8. 
84. Strathern JN Jin DJ, Court DL, Kashlev M. Isolation and characterization of transcription fidelity mutants. Biochim Biophys Acta. 2012;1819:694-9.

85. Kashkina E, Anikin M, Brueckner F, Lehmann E, Kochetkov SN, McAllister WT, Cramer P, Temiakov D. Multisubunit RNA polymerases melt only a single DNA base pair downstream of the active site. J Biol Chem. 2007;282:21578-82

86. Cheeran A, Babu Suganthan R, Swapna G, Bandey I, Achary MS, Nagarajaram HA, Sen R. Escherichia coli RNA polymerase mutations located near the upstream edge of an RNA:DNA hybrid and the beginning of the RNA-exit channel are defective for transcription antitermination by the N protein from lambdoid phage H-19B. J Mol Biol. 2005;352:28-43.

87. Kent T, Kashkina E, Anikin M, Temiakov D. Maintenance of RNADNA hybrid length in bacterial RNA polymerases. J Biol Chem. 2009;284:13497-504.

88. Sidorenkov I, Komissarova N, Kashlev M. Crucial role of the RNA:DNA hybrid in the processivity of transcription. Mol Cell. 1998;2:55-64.

89. Nudler E, Mustaev A, Lukhtanov E, Goldfarb A. The RNA-DNA hybrid maintains the register of transcription by preventing backtracking of RNA polymerase. Cell. 1997;89:33-41.

90. Chamberlin MJ. New models for the mechanism of transcription elongation and its regulation. Harvey Lect. 1992;88:1-21.

91. Blank A, Gallant JA, Burgess RR, Loeb LA. An RNA polymerase mutant with reduced accuracy of chain elongation. Biochemistry. 1986;25:5920-8

92. Bochkareva A, Yuzenkova Y, Tadigotla VR, Zenkin N. Factor-independent transcription pausing caused by recognition of the RNA-DNA hybrid sequence. EMBO J. 2012;31:630-9.

93. Vassylyev DG, Vassylyeva MN, Perederina A, Tahirov TH, Artsimovitch I. Structural basis for transcription elongation by bacterial RNA polymerase. Nature. 2007:448:157-62.

94. Belogurov GA, Artsimovitch I. Regulation of transcript elongation. Annu Rev Microbiol. 2015;69:49-69.

95. Huang J, Brieba LG, Sousa R. Misincorporation by wild-type and mutant T7 RNA polymerases: identification of interactions that reduce misincorporation rates by stabilizing the catalytically incompetent open conformation. Biochemistry. 2000;39:11571-80.

96. Peters JM, Vangeloff $A D$, Landick $R$. Bacterial transcription terminators: the RNA 3'-end chronicles. J Mol Biol. 2011;412:793-813.

97. Landick R, Yanofsky C. Stability of an RNA secondary structure affects in vitro transcription pausing in the trp operon leader region. J Biol Chem. 1984:259:11550-5.

98. Yarchuk O, lost I, Dreyfus M. The relation between translation and mRNA degradation in the lacZ gene. Biochimie. 1991;73:1533-41.

99. Peters JM, Mooney RA, Kuan PF, Rowland JL, Keles S, Landick R. Rho directs widespread termination of intragenic and stable RNA transcription. Proc Natl Acad Sci USA. 2009:106:15406-11.
100. Strauß M Vitiello C, Schweimer K, Gottesman M, Rösch P, Knauer SH. Transcription is regulated by NusA:NusG interaction. Nucleic Acids Res. 2016:44:5971-82.

101. Mohanty BK, Kushner SR. The majority of Escherichia coli mRNAs undergo post-transcriptional modification in exponentially growing cells. Nucleic Acids Res. 2006;34:5695-704.

102. Hansen MT, Bennett PM, von Meyenburg K. Intracistronic polarity during dissociation of translation from transcription in Escherichia coli. J Mol Biol. 1973:77:589-604

103. Goldberg LA. Degradation of abnormal proteins in Escherichia coli. Proc Natl Acad Sci. 1972;69:422-6.

104. Cannistraro VJ, Subbarao MN, Kennell D. Specific endonucleoIytic cleavage sites for decay of Escherichia coli mRNA. J Mol Biol. 1986:192:257-74.

105. Das A. How the phage lambda N gene product suppresses transcription termination: communication of RNA polymerase with regulatory proteins mediated by signals in nascent RNA. J Bacteriol. 1992:174:6711-6.

106. Rees WA, Weitzel SE, Das A, von Hippel PH. Regulation of the elongation-termination decision at intrinsic terminators by antitermination protein N of phage lambda. J Mol Biol. 1997;273:797-813.

107. DeVito J, Das A. Control of transcription processivity in phage lambda: Nus factors strengthen the termination-resistant state of RNA polymerase induced by $\mathrm{N}$ antiterminator. Proc Natl Acad Sci USA. 1994:91:8660-4.

108. Franklin NC, Doelling $\mathrm{JH}$. Overexpression of $\mathrm{N}$ antitermination proteins of bacteriophages lambda, 21, and P22: loss of N protein specificity. J Bacteriol. 1989;171:2513-22.

109. Rees WA, Weitzel SE, Yager TD, Das A, von Hippel PH. Bacteriophage lambda N protein alone can induce transcription antitermination in vitro. Proc Natl Acad Sci USA. 1996:93:342-6.

110. Coenye T, Vandamme P. Characterization of mononucleotide repeats in sequenced prokaryotic genomes. DNA Res. 2005:12:221-33.

111. Traverse CC, Ochman H. A genome-wide assay specifies only GreA as a transcription fidelity factor. G3 (Bethesda). 2018;8:2257-64.

112. James K, Gamba P, Cockell SJ, Zenkin N. Misincorporation by RNA polymerase is a major source of transcription pausing in vivo. Nucleic Acids Res. 2017:45:1105-13.

113. Bubunenko MG, Court CB, Rattray AJ, Gotte DR, Kireeva ML, IrizarryCaro JA, Li X, Jin DJ, Court DL, Strathern JN, Kashlev M. A Cre transcription fidelity reporter identifies GreA as a major RNA proofreading factor in Escherichia coli. Genetics. 2017;206:179-87. https://doi.org/10.1534/ genetics.116.198960

114. Imashimizu M, Oshima T, Lubkowska L, Kashlev M. Direct assessment of transcription fidelity by high-resolution RNA sequencing. Nucleic Acids Res. 2013;41:9090-104.

\footnotetext{
Ready to submit your research? Choose BMC and benefit from:

- fast, convenient online submission

- thorough peer review by experienced researchers in your field

- rapid publication on acceptance

- support for research data, including large and complex data types

- gold Open Access which fosters wider collaboration and increased citations

- maximum visibility for your research: over $100 \mathrm{M}$ website views per year
}

At BMC, research is always in progress.

Learn more biomedcentral.com/submissions 